\title{
Lymphocyte-macrophage co-operation during induction of T-suppressor cell activity in rats with adjuvant arthritis
}

\author{
LISE BINDERUP \\ From the Department of Pharmacology, Leo Pharmaceutical Products, DK-2750 Ballerup, Denmark
}

SUMMARY The role of macrophages and of macrophage-lymphocyte co-operation in the induction of T-suppressor cell activity in rats with adjuvant arthritis was investigated. Macrophages from arthritic rats had no direct effect on the induction of T-suppressor cells, but, in the presence of arthritic rats' lymphocytes or supernatants from such lymphocytes, macrophages inhibited the induction of T-suppressor cell activity. Addition of indomethacin during the induction of T-suppressor cells reduced the inhibitory effects, suggesting that prostaglandins released from lymphocyte-activated macrophages might be involved in the defective induction of T-suppressor cell activity in rats with adjuvant arthritis.

Previous investigations have shown that rats with adjuvant arthritis have a decreased level of T-suppressor cell activity after induction of suppressor cells in vitro with the polyclonal activator concanavalin-A (con-A). ${ }^{1}$ The appearance of decreased T-suppressor cell activity during the course of the disease was found to coincide with the development of the polyarthritic lesions and the extent of impairment of T-suppressor cell function was positively correlated with the severity of the lesions. This model may be of value for the investigation of suppressor cell function during chronic inflammatory diseases and may permit more detailed studies of drugs used in the treatment of conditions involving impaired suppressor cell function. ${ }^{2}$

However, the mechanism by which the induction of T-suppressor cell activity is affected during the course of adjuvant arthritis has not been studied in detail. Removal of phagocytic cells (of the monocyte/macrophage series) from the arthritic cell suspensions prior to induction of T-suppressor cells with con-A led to a normal level of suppressor cell activity. ${ }^{1}$ These results point to an important role for the macrophage in the immunoregulatory processes during adjuvant arthritis. A similar role for the macrophage during chronic inflammatory diseases in man has recently been suggested. ${ }^{34}$

In the present experiments $I$ have investigated the ability of macrophages obtained from arthritic

Accepted for publication 11 January 1983.

Correspondence to Dr L. Binderup. rats to inhibit the induction of T-suppressor cells, either by direct cell-to-cell contact or via the release of soluble factors. It was found that the macrophage exerted its suppressive effects only in the presence of arthritic lymphocytes. Supernatants from these lymphocytes could substitute for the presence of the arthritic lymphocytes during induction. Incubation with indomethacin partially reversed the inhibitory effects on the induction of T-suppressor cell activity, suggesting that prostaglandins released from macrophages were involved in the observed decrease of T-suppressor cell activity in rats with adjuvant arthritis.

\section{Materials and methods}

Induction of adjuvant arthritis. Adjuvant arthritis was induced in female inbred Lewis rats $(160-200 \mathrm{~g})$ by injecting $0.3 \mathrm{mg}$ of Mycobacterium butyricum (Difco) suspended in $0.1 \mathrm{ml}$ of mineral oil into the footpad of the right hind paw. Nonarthritic rats matched for age and weight served as controls. The severity of the disease was assessed on day 17 after adjuvant injection by measurement of the oedema of the injected and the noninjected hind paws, as previously described. ${ }^{1}$ Only rats developing oedema of the noninjected hind paw of more than $0.75 \mathrm{ml}$ were used in the subsequent experiments.

Preparation of lymphocytes and macrophages. Spleen cell suspensions were prepared from control and arthritic rats 17 days after the induction of the 
disease. The suspensions were adjusted to $20 \times 10^{6}$ nucleated cells/ml in medium RPMI 1640 (Gibco), supplemented with $2 \mathrm{mM}$ glutamine, 100 units $/ \mathrm{ml}$ penicillin, $100 \mu \mathrm{g} / \mathrm{ml}$ streptomycin, and $10 \%$ fetal calf serum (Gibco). Lymphocytes depleted of phagocytic cells were obtained by treatment with carbonyl iron particles $\left(20 \mathrm{mg} / \mathrm{ml}\right.$ for $30 \mathrm{~min}$ at $\left.37^{\circ} \mathrm{C}\right)$. Residual adherent cells were removed by a further incubation for 1 hour at $37^{\circ} \mathrm{C}$ in plastic Petri dishes. The nonadherent cells obtained after these procedures (purified lymphocytes) consisted of 98-99\% lymphocytes, as assessed by Giemsa/May-Grünwald staining. No monocytes/macrophages were detected by staining for nonspecific membrane-associated esterase by the method of Yam et al. ${ }^{5}$ Monolayers of adherent spleen cells were prepared by incubating 1 $\mathrm{ml}$ aliquots of unseparated spleen cells $\left(20 \times 10^{6}\right.$ cells $/ \mathrm{ml}$ ) in small plastic Petri dishes $\left(1\right.$ hour at $\left.37^{\circ} \mathrm{C}\right)$. After removal of nonadherent cells the monolayers contained $30-40 \%$ typical macrophages as assessed by morphology and esterase staining.

Preparation of supernatants. Monolayers of adherent spleen cells and suspensions of purified spleen lymphocytes, prepared from $20 \times 10^{6}$ unseparated spleen cells $/ \mathrm{ml}$, were incubated in culture medium for 24 hours at $37^{\circ} \mathrm{C}$. The supernatants were removed, centrifuged, sterile-filtered, and used within the same day.

Induction and assay of T-suppressor cells. T-suppressor cells were induced in cultures of purified lymphocytes $\left(20 \times 10^{6} \mathrm{cells} / \mathrm{ml}\right)$ from control or arthritic rats by incubation for 24 hours with 5 $\mu \mathrm{g} / \mathrm{ml}$ con- A, grade IV (Sigma). In some experiments the lymphocytes were incubated with monolayers of adherent cells prepared from $20 \times 10^{8}$ unseparated spleen cells $/ \mathrm{ml}$. In other experiments the lymphocytes were resuspended in supernatants obtained either from adherent spleen cells or from purified spleen lymphocytes. After culture with con-A the cells were collected, washed, treated with mitomycin $\mathrm{C}\left(30 \mu \mathrm{g} / \mathrm{ml}\right.$ for $30 \mathrm{~min}$ at $\left.37^{\circ} \mathrm{C}\right)$, and adjusted to $4 \times 10^{6} \mathrm{cells} / \mathrm{ml}$. Aliquots of $50 \mu \mathrm{l}$ were added to cultures containing $100 \mu$ l Lewis spleen cells and 100 $\mu$ l Lewis $\times$ Brown Norway $\left(F_{1}\right)$ spleen cells (MLR cultures, $4 \times 10^{6}$ cells $/ \mathrm{ml}$ in culture medium supplemented with $5 \times 10^{-5}$ M 2-mercaptoethanol). The cultures were incubated for 96 hours, the last 4 hours in the presence of ${ }^{3} \mathrm{H}$-thymidine $\left({ }^{3} \mathrm{H}\right.$-TdR, 1 $\mu \mathrm{Ci} / \mathrm{ml}, 5000 \mathrm{mCi} / \mathrm{mmol}$, the Radiochemical Centre, Amersham, England). ${ }^{3} \mathrm{H}-\mathrm{TdR}$ incorporation into cellular DNA was determined as previously described ${ }^{2}$ and expressed as disintegrations per minute $(\mathrm{dpm}) /$ culture \pm SEM. All determinations were performed in triplicate and Student's $t$ test was used for statistical analysis. Cell viability was assessed before culture and at the end of incubation by the eosin $\mathrm{Y}$ exclusion method.

\section{Results}

EFFECTS OF MACROPHAGES ON T-SUPPRESSOR CELL INDUCTION

Purified spleen lymphocytes (depleted of macrophages by treatment with carbonyl iron and by adherence to plastic) were obtained from control rats and from rats with adjuvant arthritis and cultured in the absence or presence of monolayers of adherent spleen cells from arthritic rats. T-suppressor cells were induced in these cultures by the addition of con-A $(0$ or $5 \mu \mathrm{g} / \mathrm{ml})$. Their suppressive activity was tested 24 hours later by addition to MLR cultures consisting of Lewis and Lewis $\times$ Brown Norway $\left(F_{1}\right)$ rat spleen cells.

Fig. 1 shows that con-A induced purified spleen lymphocytes from both control and arthritic rats inhibited the ${ }^{3} \mathrm{H}-\mathrm{TdR}$ incorporation in the MLR cultures to the same extent (by $52 \%$ and $43 \%$, respec-

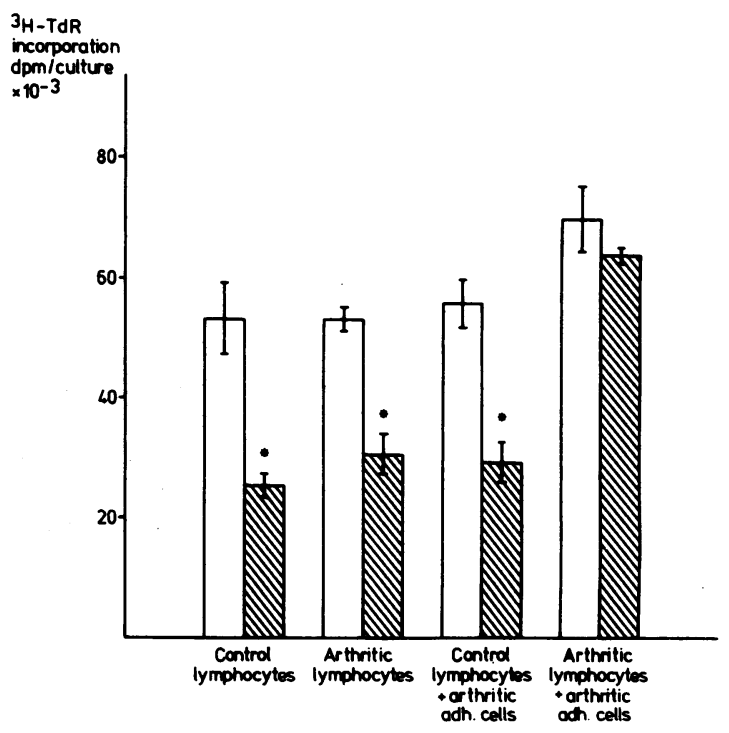

Fig. 1 Effect of adherent cells on T-suppressor cell induction. T-suppressor cells were induced in cultures of purified spleen lymphocytes $\left(20 \times 10^{6}\right.$ cells $\left./ \mathrm{ml}\right)$ obtained from control rats or from rats with adjuvant arthritis 17 days after the induction of the disease. Half of these cultures were supplemented with adherent spleen cells obtained from $20 \times 10^{6}$ cells $/ \mathrm{ml}$ of unseparated arthritic spleen cells. The induced suppressor cells were treated with mitomycin-C and added to MLR cultures of Lewis and Lewis $\times$ Brown Norway $\left(F_{1}\right)$ spleen cells. The columns show the incorporation of ${ }^{3} H-T d R$ in the various $M L R$ cultures as mean dpm/culture $\pm S E M$ of 3 experiments. Unshaded $=0$ $\mu \mathrm{g} / \mathrm{ml}$ con- $A$, shaded $=5 \mu \mathrm{g} / \mathrm{ml}$ con- $A$. The asterisks indicate cultures with con-A-induced $T$-suppressor cell activity significantly different from the corresponding cultures supplemented with cells without con-A-pretreatment. 
tively). The presence of adherent spleen cells from arthritic rats (containing $40 \%$ macrophages) did not affect the induction of T-suppressor cells in cultures with purified spleen lymphocytes from control rats ( $47 \%$ inhibition of MLR). On the contrary, no significant $\mathrm{T}$-suppressor cell activity was induced in cultures with both arthritic adherent spleen cells and arthritic lymphocytes ( $9 \%$ inhibition of MLR). These results show that the macrophages in the arthritic adherent spleen cell preparations could interfere with the induction of T-suppressor cell activity only in the presence of arthritic lymphocytes.

Fig. 2 shows furthermore that macrophages from control and arthritic rats, cultured in the absence of added lymphocytes, did not release soluble inhibitors of T-suppressor cell induction into the medium. Supernatants were collected from adherent spleen cells after 24 hours of culture and added to purified control lymphocytes during the induction of

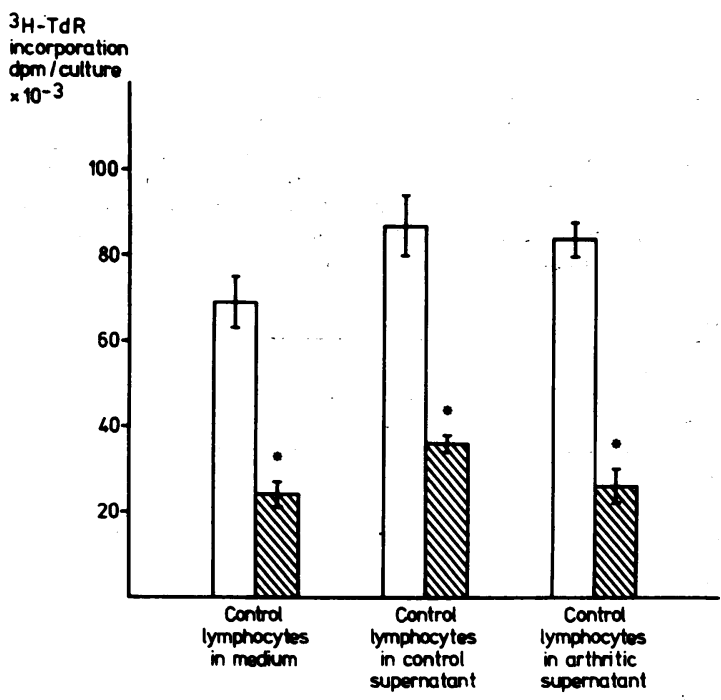

Fig. 2 Effect of supernatants from adherent cells on $T$-suppressor cell induction. T-suppressor cells were induced in cultures of purified spleen lymphocytes from control rats $\left(20 \times 10^{6}\right.$ cells $\left./ \mathrm{ml}\right)$, resuspended in medium or in supernatant obtained from a 24-hour culture of adherent spleen cells. Adherent spleen cells were prepared from suspensions of unseparated spleen cells $\left(20 \times 10^{6}\right.$ cells $\left./ \mathrm{ml}\right)$ from control rats or from rats with adjuvant arthritis 17 days after the induction of the disease. The induced suppressor cells were treated with mitomycin-C, adjusted to $4 \times 10^{6}$ cells $/ \mathrm{ml}$, and added to $M L R$ cultures. The columns show the incorporation of ${ }^{3} \mathrm{H}-T d R$ in the various $M L R$ cultures as mean dpm/culture $\pm S E M$ of 3 experiments. Unshaded $=0$ $\mu \mathrm{g} / \mathrm{ml}$ con- $A$, shaded $=5 \mu \mathrm{g} / \mathrm{ml}$ con- $A$. The asterisks indicate cultures with con-A-induced $T$-suppressor cell activity significantly different from the corresponding cultures supplemented with cells without con-A pretreatment.
T-suppressor cells with con-A. MLR cultures were inhibited by $59 \%$ by suppressor cells from cultures with supernatant from control adherent cells and by $69 \%$ by suppressor cells from cultures with supernatant from arthritic adherent cells. Cells from cultures with no added supernatant (medium alone) inhibited MLR ${ }^{3} \mathrm{H}-\mathrm{TdR}$ incorporation by $65 \%$.

EFFECTS OF MACROPHAGE-LYMPHOCYTE INTERACTION ON T-SUPPRESSOR CELL INDUCTION

The effects of supernatants prepared from purified spleen lymphocytes obtained from control and arthritic rats were next investigated. The supernatants were collected after 24 hours of culture and added to cultures of purified spleen lymphocytes from control rats, in the presence or absence of adherent spleen cells, during the induction of $\mathrm{T}$-suppressor cells (Table 1). No significant effects on T-suppressor cell activity were observed when supernatants from control or arthritic lymphocytes were added to cultures of lymphocytes alone $(68 \%$ and $72 \%$ inhibition of MLR ${ }^{3} \mathrm{H}-\mathrm{TdR}$ incorporation, respectively). On the other hand supernatants from arthritic, but not from control lymphocytes, decreased the induction of T-suppressor cell activity in the presence of either control or arthritic adherent cells. The largest effect was seen with cultures containing arthritic adherent cells ( $4 \%$ inhibition, compared with $26 \%$ inhibition with cultures containing control adherent cells). Dialysis of the supernatants prior to use did not abolish the observed effects, but after storage at $-20^{\circ} \mathrm{C}$ for 1 week the activity of the supernatants was entirely lost.

These results suggest that purified spleen lymphocytes from arthritic rats may, via the production of a soluble factor, induce or 'activate' macrophages to interfere with the normal induction of $\mathrm{T}$-suppressor cell activity.

EFFECT OF INDOMETHACIN ON T-SUPP.RESSOR CELL INDUCTION

Since macrophages are known to be able to release prostaglandins with immunosuppressive activities on interaction with a variety of stimuli, the possibility was investigated that prostaglandins were involved in the decreased induction of T-suppressor cell activity during adjuvant arthritis. Indomethacin $(1 \mu \mathrm{g} / \mathrm{ml})$ was added to cultures of purified spleen lymphocytes from control or arthritic rats, in the presence of adherent spleen cells, during the induction of T-suppressor cells with con-A. Table 2 shows that indomethacin had no effect on T-suppressor cell activity when added to cultures of control lymphocytes and control adherent cells (54\% inhibition of MLR ${ }^{3} \mathrm{H}-\mathrm{TdR}$ incorporation with cells from cultures 
Table 1 Effect of lymphocyte supernatants on T-suppressor cell induction

\begin{tabular}{|c|c|c|c|c|}
\hline $\begin{array}{l}\text { Cultures for } \\
\text { suppressor cell } \\
\text { induction }\end{array}$ & $\begin{array}{l}\text { Con-A } \\
\text { pretreatment } \\
\mu g / m l\end{array}$ & $\begin{array}{l}\text { 'H-TdR incorporation } \\
\text { in } M L R \\
\text { dpm/culture } \pm S E M\end{array}$ & $\begin{array}{l}\text { \% Change } \\
\text { in }{ }^{2} H-T d R \\
\text { incorporation }\end{array}$ & $p$ \\
\hline \multirow{2}{*}{$\begin{array}{l}\text { Control lymphocytes } \\
\text { +control supematant }\end{array}$} & 0 & $100490 \pm 8008$ & & \\
\hline & 5 & $31984 \pm 3223$ & -68 & $<0.005$ \\
\hline \multirow{2}{*}{$\begin{array}{l}\text { Control lymphocytes } \\
\text { +arthritic supematant }\end{array}$} & 0 & $97713 \pm 2901$ & & \\
\hline & 5 & $27475 \pm 3330$ & -72 & $<0.001$ \\
\hline \multirow{2}{*}{$\begin{array}{l}\text { Control lymphocytes } \\
\text { + control adherent cells } \\
\text { +control supernatant }\end{array}$} & 0 & $74750 \pm 8865$ & & \\
\hline & 5 & $28250 \pm 1645$ & -62 & $<0.01$ \\
\hline \multirow{2}{*}{$\begin{array}{l}\text { Control lymphocytes } \\
\text { +control adherent cells } \\
\text { +arthritic supernatant }\end{array}$} & 0 & $84714 \pm 7478$ & & \\
\hline & 5 & $63015 \pm 4662$ & -26 & NS \\
\hline \multirow{2}{*}{$\begin{array}{l}\text { Control lymphocytes } \\
\text { +arthritic adherent cells } \\
\text { +control supernatant }\end{array}$} & 0 & $94881 \pm 2119$ & & \\
\hline & 5 & $35347 \pm 5409$ & -63 & $<0.001$ \\
\hline \multirow{2}{*}{$\begin{array}{l}\text { Control lymphocytes } \\
\text { +arthritic adherent cells } \\
\text { +arthritic supernatant }\end{array}$} & 0 & $88547 \pm 9007$ & & \\
\hline & 5 & $85141 \pm 2214$ & -4 & NS \\
\hline
\end{tabular}

Supernatants were obtained from purified spleen lymphocytes from control or arthritic rats after 24 hours of culture $\left(20 \times 10^{6}\right.$ cells/ml). Control purified lymphocytes were resuspended in the supernatants and used for the induction of T-suppressor cells $(0$ or $5 \mu \mathrm{g} / \mathrm{ml}$ con-A) in the absence or presence of adherent cells from control or arthritic spleens. The induced suppressor cells were treated with mitomycin-C and added to MLR cultures. ${ }^{3} \mathrm{H}-\mathrm{TdR}$ incorporation in the MLR cultures was determined after 96 hours of incubation and expressed as mean $\mathrm{dpm} /$ culture \pm SEM of 3 experiments. $p$ Values indicate a significant difference in ${ }^{2} \mathrm{H}-\mathrm{TdR}$ incorporation between cultures supplemented with con-A-induced cells and cultures supplemented with cells without con-A pretreatment. NS=not significant.

Table 2 Effect of indomethacin on T-suppressor cell induction

\begin{tabular}{|c|c|c|c|c|}
\hline $\begin{array}{l}\text { Cultures for } \\
\text { suppressor cell } \\
\text { induction }\end{array}$ & $\begin{array}{l}\text { Con-A } \\
\text { treatment } \\
\mu g / m l\end{array}$ & $\begin{array}{l}{ }^{2} H-T d R \text { incorporation } \\
\text { in } M L R \\
\text { dpm/culture } \pm S E M\end{array}$ & $\begin{array}{l}\text { \% Change } \\
\text { in }{ }^{2} H-T d R \\
\text { incorporation }\end{array}$ & $p$ \\
\hline \multirow{2}{*}{$\begin{array}{l}\text { Control lymphocytes } \\
\text { +control adherent cells }\end{array}$} & 0 & $74224 \pm 2985$ & & \\
\hline & 5 & $33902 \pm 3813$ & -54 & $<0.005$ \\
\hline \multirow{2}{*}{$\begin{array}{l}\text { Control lymphocytes } \\
\text { + control adherent cells } \\
\text { +indomethacin }\end{array}$} & 0 & $78669 \pm 1910$ & & \\
\hline & 5 & $39507 \pm 3004$ & -50 & $<0.001$ \\
\hline \multirow{2}{*}{$\begin{array}{l}\text { Arthritic lymphocytes } \\
\text { + arthritic adherent cells }\end{array}$} & 0 & $87477 \pm 7497$ & & \\
\hline & 5 & $80846 \pm 6413$ & -8 & NS \\
\hline \multirow{2}{*}{$\begin{array}{l}\text { Arthritic lymphocytes } \\
\text { + arthritic adherent cells } \\
\text { +indomethacin }\end{array}$} & 0 & $64975 \pm 5526$ & & \\
\hline & 5 & $44864 \pm 3678$ & -31 & $<0.05$ \\
\hline
\end{tabular}

Indomethacin $(1 \mu \mathrm{g} / \mathrm{ml})$ was added to cultures of control or arthritic purified spleen lymphocytes $\left(20 \times 10^{\circ}\right.$ cells/ml) reconstituted with adherent spleen cells. T-suppressor cells were induced with con-A $(0$ or $5 \mu \mathrm{g} / \mathrm{ml})$. The induced suppressor cells were treated with mitomycin-C and added to MLR cultures. ${ }^{3} \mathrm{H}-\mathrm{TdR}$ incorporation in the MLR cultures was determined after 96 hours of incubation. The results were expressed as described in the footnote to Table 1.

without indomethacin, $50 \%$ inhibition with cells from cultures with indomethacin). On the contrary, addition of indomethacin to cultures of arthritic lymphocytes and arthritic adherent cells partially inhibited the decrease in T-suppressor cell activity observed in cultures without indomethacin $(31 \%$ inhibition with indomethacin, compared to $8 \%$ without indomethacin). Indomethacin had no effect on the induction of suppressor cells in cultures of lymphocytes alone, nor did indomethacin effect ${ }^{3} \mathrm{H}-\mathrm{TdR}$ incorporation when added directly to the MLR cultures (results not shown). 


\section{Lymphocyte-macrophage co-operation during induction of T-suppressor cell activity}

\section{Discussion}

Adjuvant arthritis is a chronic polyarthritis induced in susceptible strains of rats by the injection of Mycobacterium butyricum in mineral oil. Both histopathological and immunopathological parameters suggest that this disease mimics some of the features of rheumatoid arthritis. ${ }^{6}$ Cell-mediated immunological reactions are thought to play an important role in the pathogenesis of the disease, ${ }^{7}$ and previous experiments have shown that the response of spleen and lymph node cells to T-cell mitogens is depressed during the course of adjuvant arthritis. ${ }^{8-10}$ In addition, recent investigations have shown that con-Ainduced T-suppressor cell activity is also decreased in rats with adjuvant arthritis. ${ }^{1}$ The potential role of T-suppressor cells in the pathogenesis of adjuvant disease is suggested by the findings that treatment prior to the induction of the disease with agents that deplete suppressor cells (such as thymectomy, irradiation, or cyclophosphamide) enhance the severity of the disease, whereas treatment with antithymocyte serum, which selectively depletes inducer T-cells, decreases the severity of the disease. ${ }^{11}$

The present experiments deal with the role of macrophages and lymphocyte/macrophage co-operation in the induction of T-suppressor cell activity in rats with adjuvant arthritis. Macrophages, as characterised by morphology, adherence to plastic, phagocytic uptake of carbonyl iron particles, and presence of membrane-associated esterase, were previously found to be involved in the decreased induction of T-suppressor cells, as removal prior to induction with con-A resulted in a normal level of T-suppressor cell activity. ${ }^{1}$ The present investigations show that macrophages from arthritic rats did not directly, or by the release of soluble inhibitors, interfere with the induction of T-suppressor cells. This phenomenon occurred only when lymphocytes from arthritic rats were added to the cultures, and could be replaced by supernatants obtained from such lymphocytes but not by supernatants from control lymphocytes. The supernatant activity was found to be nondialysable and unstable upon prolonged storage. Lymphocyte-derived factors that exert nonspecific or specific suppressor activity, possibly through the activation of macrophages, have repeatedly been described. ${ }^{12}$ These factors include lymphokines, such as soluble immune response suppressor (SIRS), low-molecular-weight activator of suppressor monocytes (LASM), and macrophage activating/arming factor (MAF). Imbalance in the production or activity of these factors may be involved in the pathogenesis of a number of immunological disorders, as suggested by the decrease in SIRS production and suppressor cell activity in old NZB/NZW mice with autoimmune murine lupus. ${ }^{13}$ Clearly the relationship between these factors and the supernatant factor(s) produced by lymphocytes from arthritic rats merits further investigation.

If macrophages are activated or stimulated by lymphocyte-derived factors to interfere with the induction of T-suppressor cells, several effector mechanisms may be envisaged. Macrophages may by direct cell-to-cell contact with the precursor T-cells inhibit the induction of suppressor cells, by a mechanism analogous to that whereby activated macrophages inhibit the growth of tumour cells in vitro. ${ }^{14}$ Activated macrophages also release a number of soluble products such as enzymes, complement components, oxygen metabolites, interferon, and prostaglandins that may interfere with lymphocyte functions. ${ }^{15}$ Recently considerable interest has been directed to the role of prostaglandins as mediators of immunoregulatory functions. Prostaglandins, especially $\mathrm{PGE}_{2}$ and 6-keto-PGF ${ }_{1} \alpha$, are released in large amounts by stimulated macrophages. ${ }^{16} \mathrm{PGE}_{2}$ may act as an immunosuppressive agent by inhibiting lymphocyte responses to antigens and cell-mediated cytoxicity. ${ }^{17} \mathrm{PGE}_{2}$ may also inhibit the induction of T-suppressor cells as inhibitors of prostaglandin synthetase have been reported to increase the conA-induced suppressor cell activity. ${ }^{18}$ In the present experiments indomethacin was added to cultures of arthritic spleen cells during the induction of T-suppressor cells. A partial reversal of the inhibition of T-suppressor cell induction was observed, suggesting that prostaglandins released by lymphocyteactivated macrophages may mediate some of the observed inhibitory effects. Other mediators, however, may be involved, as complete abrogation of the inhibitory effects was not achieved.

In conclusion, the present experiments suggest that lymphocytes from arthritic rats produce a soluble factor(s) that induce or activate macrophages to exert an inhibitory effect on the generation of T-suppressor cells, possibly through the release of prostaglandins and/or other macrophage-derived mediators. This model may be of value for the investigation of suppressor cell activity in chronic inflammatory disease and lends itself to the investigation of immunoregulatory drugs. The described experimental system should enable us to distinguish between treatments that interfere with the induction of activating factors released by arthritic rats' lymphocytes and treatments that may interfere with the effector functions of the macrophage.

The author wishes to thank Professor E. Arrigoni-Martelli for helpful advice and discussion. The valuable technical assistance of Ms B. Rumler, Ms B. Hasselriis, and Ms E. Greve Petersen is gratefully acknowledged. 


\section{Binderup}

\section{References}

1 Binderup L. Decreased T-suppressor cell activity in rats with adjuvant arthritis. Ann Rheum Dis 1983; 42: 693-98.

2 Waldmann T A, Blaese R M, Broder S, Krakauer R S. Disorders of suppressor immunoregulatory cells in the pathogenesis of immunodeficiency and autoimmunity. Ann Intern Med 1978; 88: 226-38.

3 Janossy G, Panayi G, Duke O, Bofill M, Poulter L W, Goldstein G. Rheumatoid arthritis: a disease of T-lymphocyte/macrophage immunoregulation. Lancet 1981; ii: 839-40.

4 Klareskog L, Forsum U, Scheynius A, Kabelitz D, Wigzell H. Evidence in support of a selfperpetuating HLA-DR-dependent delayed-type cell reaction in rheumatoid arthritis. Proc Nat Acad Sci USA 1982; 79: 3632-6.

5 Yam L T, Liand C Y, Crosby W H. Cytochemical identification of monocytes and granulocytes. Am J Clin Pathol 1971; 55: 283-90.

6 Pearson C M, Wood F D. Studies of arthritis and other lesions induced in rats by the injection of mycobacterial adjuvant. VII. Pathological details of the arthritis and spondylitis. Am J Pathol 1963; 42: 73-86.

7 Waksman B H, Pearson C M, Sharp J T. Studies of arthritis and other lesions induced in rats by injection of mycobacterial adjuvant. II. Evidence that the disease is a disseminated immunological response to exogenous antigen.J Immunol 1960; 85: 403-17.

8 Kourounakis L, Kapusta M A. Effect of Freund's adjuvant on the mitogenic responses of rat lymphocytes. Ann Rheum Dis 1974; 33: 185-9.
9 Binderup L, Bramm E, Arrigoni-Martelli E. Splenic suppressor cells in adjuvant arthritic rats: effect of D-penicillamine. Agents Actions 1980; suppl 7: 199-203.

10 Binderup L, Bramm E, Arrigoni-Martelli E. Immunological effects of D-penicillamine during experimentally induced inflammation in rats. Scand J Immunol 1980; 12: 239-47.

11 Rosenthale M E, Capetola $R$ J. Adjuvant arthritis: immunopathological and hyperalgesic features. Fed Proc 1982; 41: 2577-82.

12 Pierce C W, Tadakuma T, Kapp J A. Role of nonspecific and specific suppressor factors in immunity. Ann N Y Acad Sci 1980; 332: 336-44.

13 Krakauer R S, Waldmann TA, Strober W. Loss of suppressor T cells in adult NZB/NZW mice. $J$ Exp Med 1976; 144: 662-73.

14 Keller R. Cytostatic and cytocidal effects of activated macrophages. In: Nelson D S, ed. Immunobiology of the macrophage. New York: Academic Press, 1976: 487-508.

15 Gery I, Davies P. Immunoregulatory products of macrophages. In: Cohen S, Pick E, Oppenheim J J, eds. Biology of the lymphokines. New York: Academic Press, 1979: 347-67.

16 Humes J L, Bonney R J, Pelus L, et al. Macrophages synthesize and release prostaglandins in response to inflammatory stimuli. Nature 1977; 269: 149-51.

17 Goodwin J S, Webb D R. Regulation of the immune response by prostaglandins. Clin Immunol Immunopathol 1980; 15: 106-22.

18 Skoldstam L, Zoschke D, Messner R. Increase in con-A-induced suppressor cell activity after indomethacin treatment. Arthritis Rheum 1982; 25: 357-9. 